\title{
CLINICAL PROFILE AND OUTCOME OF PEDIATRIC MAINTENANCE HEMODIALYSIS A PROSPECTIVE, OBSERVATIONAL, HOSPITAL BASED STUDY.
}

\begin{tabular}{ll}
$\begin{array}{l}\text { Prasant Kumar } \\
\text { Pandey }\end{array}$ & $\begin{array}{l}\text { Consultant, Paediatrics \& Neonatology , Bright Star Multispeciality } \\
\text { Hospital, New Moradabad, India }\end{array}$ \\
\hline $\begin{array}{l}\text { Peerzada Owais } \\
\text { Ahmad* }\end{array}$ & $\begin{array}{l}\text { SR, Paediatrics, ABVIMS ,PGIMER, DR RMLH, New Delhi, India. } \\
\text { *Corresponding Author }\end{array}$ \\
\hline Nomeeta Gupta & $\begin{array}{l}\text { Senior Consultant \& H.O.D Paediatrics ,Batra Hospital \& Medical Research } \\
\text { Centre,New Delhi,India }\end{array}$ \\
\hline Amit Agarwal & $\begin{array}{l}\text { Senior Consultant, Pediatric Nephrology, Batra Hospital \& Medical } \\
\text { Research Centre, New Delhi. }\end{array}$ \\
\hline \hline
\end{tabular}

ABSTRACT Introduction: Dialysis forms the cornerstone of therapy for most patients with chronic kidney diseases stage V, End Stage Renal Disease (ESRD) and many patients with Acute Kidney Injury (AKI). Congenital disorders, including congenital anomalies of the kidney and urinary tract (CAKUT) and hereditary nephropathies, are responsible for about two thirds of all cases of CKD in developed countries, while glomerulonephritis in developing countries predominates as cause for CKD. Most paediatric patients continue to have haemodialysis till a source becomes available for renal transplant, some may die waiting kidney transplant due to complications and some might change dialysis centre at parents wish.

Aims: To identify the causes of Chronic Kidney Disease in children and to assess the outcome and impact of paediatric haemodialysis on Growth parameters and on laboratory parameters.

Materials And Methods: this study is Prospective observational hospital based study done at Pediatric hemodialysis centre at Department of Pediatrics and Neonatology, Batra Hospital and Medical Research Centre, New Delhi. Patients coming to Batra hospital for pediatric maintenance hemodialysis were study subjects. A total of 50 patients were taken up for study. Detailed history taking, clinical examination and relevant investigations of subjects were done. Dialysis had been performed with Fresenius 2008K machines and hollow fiberpolysulfone dialysis filters (Fresenius, Bad Homburg, Germany), using standard bicarbonate dialysis solution. Following hemodialysis procedure the child was followed till the end point.

Results: . Our study showed prevalence of CKD more in males. In our study out of 50 cases 27(54\%) cases wer found to be having glomeruolnephritis as a cause of CKD. In our study out of 50 cases :30 (60\%)cases were followed till the end of study 9 (18\%)cases terminated dialysis on parent's wish and dialysis may be continued at another centre.6 $(12 \%)$ cases died during the study period And $5(10 \%)$ cases underwent renal transplantation. Height improved on follow up and lab. Parameters like $\mathrm{Hb}$, phosphate,crea also improved.

Conclusion: This study showed that in developing countries set up most common cause of CKD in paediatric age group is Glomerulonephritis followed by CAKUT and other congenital anomalies of urinary tract. Haemodialysis in children improves height, anemia, and other lab. Parameters like phosphate, creatinine and others. Most paediatric patients followed maintenance haemodialysis till end of study, some died, and some shifted to other haemodialysis centre while about $10 \%$ cases underwent kidney transplantation. There is a greater need for establishing multiple pediatric haemodialysis centres all over India, including rural set up for increasing the long term survival in pediatric patients with CKD ,ESRD and improving their quality of life.

\section{KEYWORDS : Hemodialysis, Glomerulonephritis, Kidney Transpant}

\section{INTRODUCTION}

Dialysis forms the cornerstone of therapy for most patients with chronic kidney disease Stage V, End Stage Renal Disease (ESRD) and many patients with Acute Kidney Injury (AKI). The clinical use of an "artificial kidney" was pioneered in1944 in adult patients suffering from acute renal failure by Willem J ("Pim") Kolff ${ }^{[1,2]}$, a Dutch physician in Nazi-occupied Holland during the Second World War. Kolff's interest in dialysis grew from his experiences caring for young patients with renal failure for whom treatment options were essentially nonexistent at that time. Paediatric application of the kolff artificial kidney was First Reported in 1950 By john Merrill and his colleagues in boston who included a $3^{1 / 2}$ Year Old boy with nephritic syndrome in their initial series of 42 adult patients Dialyzed using a rotating drum machine essentially the same as kolff's original design ${ }^{[3]}$ Provision of pediatric hemodialysis (HD) Requires a Specialized and integrated health-Care team to manage the medica l,Nursing, Nutrition ,Development ,And psychosocial aspects of care for children with ESRD. Children should be hemodialyzed in dedicated pediatric dialysis units, With A Multidisciplinary Support Team, Which Supports Individualized And Integrated therapy.
Since the expense and commitment in terms of man power and equipment required for such units is considerable, With few Exceptions, Children in most developing countries, Especially in asia, Are dialyzed in adult units . Most centers are located in cities, Are in the private Sector, And have limited accessibility to all Sections of The society.Children Bear The Brunt Of Lack Of Dedicated hemodialysis Services.

\section{Indications for Hemodialysis}

- For older children hemodialysis is applied for drop-outs from the peritoneal dialysis program or if there are medical (rare) or psychosocial (more often) reasons for not performing Peritoneal dialysis ${ }^{[4]}$.

- Age of the child (30\%)

- Parent choice (27\%)

- Distance from unit (14\%)

- Patient choice (11\%)

- Social condition (7\%)

- Unable to do one mode (6\%)

- There are more than 7,000 children and adolescents in the United States with End Stage Renal Disease (ESRD) $\left[{ }^{5]}\right.$.Pediatric patients with ESRD (aged 0 to 19 years) 
have mortality rates 150 times those of the general pediatric population $\left[{ }^{6]}\right.$ and are hospitalized often. Currently, little clinical evidence exists to guide the care of adolescent dialysis patients to improve clinical outcomes.

The prevalence of chronic kidney disease in children continues to increase worldwide due at least in part to increased survival and better treatment for chronic conditions, including those of renal etiology as well as other, non renal conditions Hemodialysis provides an excellent extracorporeal mode for renal replacement therapy. Advances in technical aspects in hemodialysis and the availability of pediatric size dialyzers and equipment have made it possible to offer hemodialysis to children with end stage renal disease.

A Hemodialysis System consists of a blood circuit, a dialysate circuit, and a dialyzer separating both circuits by a semi permeable filter membrane. The blood circuit includes a vascular access device, blood tubes (arterial and venous lines), one or two blood pumps, pressure and air leak monitors, and security clamps. A separate pump delivers anticoagulants to prevent clotting in the arterial site of the extracorporeal blood circuit. The dialysate circuit requires at least one or two dialysis fluid pumps, and systems for ultra filtration control and heating of the dialysis fluid. The composition of the dialysis fluid, the flow rates and pressures, and the presence of blood in the dialysate are continuously monitored. Most devices designed for routine maintenance hemodialysis provide water purification, degassing, and preparation of the dialysate from purified water and electrolyte/buffer concentrates. The dialyzer as the central component of the hemodialysis system consists of a semi permeable filter membrane to remove metabolic waste products, electrolytes, and excess of water.

Immediate dialysis requires placement of a catheter in a central large caliber vein so that enough flow can be generated to dialyze a patient in $<4$ hours. There is currently no AVF that can be used immediately for hemodialysis, and AVGs have a higher complication rate if used immediately. Therefore, temporary-access catheters are often used when dialysis must be performed in less than 3 to 4 weeks and there is inadequate time for the chronic access fistula or graft to mature ${ }^{[9]}$. Among the Renal Replacement Therapy (RRT) modalities available, Hemodialysis is the most commonly used initial therapy and is the most commonly used dialytic modality long term ${ }^{[10]}$. Children with end-stage renal disease (ESRD) in industrialized countries have much better prognoses than their counterparts in developing countries, as access for the latter to dialysis and transplantation is limited ${ }^{[11]}$.

There are some fundamental differences between adult and pediatrichemodialysis practice -in pediatric practice, blood lines and the hemodialyzer are selected on the basis that children can tolerate $8 \%$ (absolute maximum 10\%) of their total blood volume in the extracorporeal circuit, based on total blood volume estimated as $80 \mathrm{~mL} / \mathrm{kg}$ for infants and $70 \mathrm{~mL} / \mathrm{kg}$ for older children. If the extracorporeal blood volume exceeds $10-15 \%$ of the patient's total blood volume, a blood prime is recommended ${ }^{[12]}$. Depending on the hemodynamic status of the patient, the lines may still need to be primed with $0.9 \%$ saline or $5 \%$ albumin, even if this volume is not exceeded ${ }^{[13]}$.

Chronic kidney disease (CKD) is the new term defined by the National Kidney Foundation Kidney Disease and Outcome Quality Initiative (KDOQI) Group to classify any patient who has kidney damage lasting for at least 3 months with or without a decreased GFR or any patient who has a GFR of less than $60 \mathrm{~mL} / \mathrm{min}$ per $1.73 \mathrm{~m}^{2}$ lasting for 3 months with or without kidney damage. The KDOQI Group also classified CKD into five stages ${ }^{[15]}$ :

- Stage 1: Kidney damage with a normal or increased GFR $\left(>90 \mathrm{~mL} / \mathrm{min}\right.$ per $1.73 \mathrm{~m}^{2}$ )
- Stage 2: Mild reduction in the GFR (60 to $89 \mathrm{~mL} / \mathrm{min}$ per $1.73 \mathrm{~m}^{2}$ )

- Stage 3: Moderate reduction in the GFR (30 to $59 \mathrm{~mL} / \mathrm{min}$ per $1.73 \mathrm{~m}^{2}$ )

- Stage 4: Severe reduction in the GFR (15 to $29 \mathrm{~mL} / \mathrm{min}$ per $1.73 \mathrm{~m}^{2}$ )

- Stage 5: Kidney failure (GFR $<15 \mathrm{~mL} / \mathrm{min}$ per $1.73 \mathrm{~m}^{2}$ or dialysis)

GFR values for CKD staging are for children older than 2 years of age because the GFR values for younger children are low due to ongoing renal maturation.

\section{CAUSES OF CKD:}

Congenital disorders, including congenital anomalies of the kidney and urinary tract (CAKUT) and hereditary nephropathies, are responsible for about two thirds of all cases of CKD in developed countries, while acquired causes predominate in developing countries ${ }^{[16]}$.

Although kidney transplantation is preferred, many children with ESRD are likely to require dialysis therapy initially prior to transplantation and again after eventual loss of a kidney transplant later in childhood or as an adult. The care that these children receive while on dialysis therapy is crucial to minimize life-long medical complications associated with ESRD, to optimize outcomes during time on dialysis therapy and subsequent transplantation, and to maximize overall quality of life (QoL) and social productivity.

Extracorporeal volume: With the use of catheters, smallhemodialyzers, and smaller volume blood tubing, the extracorporeal blood volume often can be maintained at ,8\%$10 \%$ of the intravascular volume. Blood tubing is available in 3 sizes that vary in their priming volume: neonatal $25 \mathrm{~mL}$, pediatric $75 \mathrm{~mL}$, and adult $127 \mathrm{~mL}$. The extracorporeal circuit volume includes the dialyzer priming volume and the volume of the blood tubing. If this volume is . $10 \%$ of the total blood volume, blood or $5 \%$ albumin should be used to prime the blood tubing and dialyzer.

Blood flow rate: Blood flow rates generated by the dialysis pump usually range from $3-5 \mathrm{~mL} / \mathrm{kg}$ of body weight perminute, often starting at the lower blood flow rate and slowly increasing the rate during the procedure.

Ultrafiltration: Ultrafiltration is the movement of fluid under hydrostatic pressure from the blood to the dialysate compartment. The amount ultrafiltered depends on transmembrane pressure, the pressure difference between the blood and dialysate compartments. The maximum ultrafiltration rate is $0.2 \mathrm{~mL} / \mathrm{kg} / \mathrm{min}$.ate. The standard dialysate flow rate is $500 \mathrm{~mL} / \mathrm{min}$.

Anticoagulation:Anticoagulation with heparin is provided during the HD procedure, typically with a pre- HD infusion of $10-20 \mathrm{U} / \mathrm{kg} /$ dose, with bedside monitoring of the activated clotting time.

The complications associated with HD in infants and children include problems related to vascular access, including thrombosis, stenosis, and infection. Given their increased susceptibility to hypothermia, infants typically are dialyzed against higher dialysate temperatures of $37.5 \mathrm{C}-38 \mathrm{C}$ in combination with external warming strategies.

Muscle cramping may occur during the HD treatment and may be related to hypovolemia, hypotension, and electrolyte shifts. Dialysis disequilibrium syndrome occurs in children, with symptoms often resembling those of hypovolemia. Children at risk often have calculated or measured osmolality .> 330 $\mathrm{mOsm} / \mathrm{kg}$ (in the setting of elevated serum urea nitrogen 
[SUN], sodium, or glucose levels), preexisting neurologic disease, severe metabolic acidosis, and high ultrafiltration goal. Manifestations include headache, nausea, vomiting, blurred vision, restlessness, and,in severe situations, significant mental status disturbances, including disorientation and coma ${ }^{[3]]}$.

\section{AIMS AND OBJECTIVES}

\section{Primary Objective:}

To Identify the causes Chronic Kidney Disease in patients in pediatric age group with Chronic Kidney Disease on haemodialysis.

\section{SecondaryObjectives:}

To assess the outcome and impact of pediatrichemodialysis:

- On growth parameters (mainly height and weight)

- On laboratory parameters (especially calcium/ phosphate/Hb/iPTH)outcome

\section{MATERIALS AND METHODS}

This study is Prospective observational hospital based study done at Pediatric hemodialysis centre at Department of Pediatrics and Neonatology, Batra Hospital and Medical Research Centre, New Delhi. Patients coming to Batra hospital for pediatric maintenance hemodialysis were study subjects. A total of 50 patients were taken up for study. Detailed history taking, clinical examination and relevant investigations of subjects were done. Dialysis had been performed with Fresenius 2008K machines and hollow fiberpolysulfone dialysis filters (Fresenius, Bad Homburg, Germany), using standard bicarbonate dialysis solution. Following hemodialysis procedure the child was followed till the end point.

\section{INCLUSION CRITERIA:}

1. Paediatric patients suffering from Chronic Renal Failure.

2. Duration of renal failure of more than 12 weeks.

3. Age of 18 years or under.

\section{EXCLUSION CRITERIA:}

1. Pediatric patients suffering from failure of kidneys for less than 12 weeks.

2. Pediatric patients having Acute Kidney Injury

\section{METHODOLOGY:}

After taking approval from ethical committee of the hospital, we obtained informed consent after detailed explanation to parents/ guardian. All pediatric patients undergoing maintenance hemodialysis at pediatric hemodialysis centre at Batra Hospital subjected to thorough history taking, clinical examination and relevant investigations. Subjects for the study selected after applying the inclusion criteria as stated above. Each subject underwent a given set of investigations (Hemoglobin, Serum Bilirubin, Aspartate Aminotransferase (AST), Alanine Aminotransferase (ALT), Random Blood Sugar (RBS), blood counts - Total Leukocyte Count, Differential Leukocyte Count, Haematocrit, hemoglobin, Renal Function Test (RFT),Intact Parathyroid Hormone (iPTH), serum iron (Fe) studies \& viral serology for Hepatitis B surface antigen, Hepatitis $\mathrm{C}$ virus, and Human Immunodeficiency Virus) which were repeated after 3 months

Following this procedure the child was followed till the end point:

- Termination of dialysis at our centre on parent's wish.

- child undergoing renal transplant,

- death of child or

- end of study period.

- Statistical methods for analysis of results: Data tabulated in MS Office Excel worksheet. Descriptive statistics computed for all the numerical data. Frequency tables constructed for categorical data. Chi square test used to test for association between the categorical data.
For all the statistical analysis a $P$ value $\leq .05$ are considered to indicate as significant difference at $5 \%$ level of significance. All statistical analysesperformed by using software SPSS version 16.0

\section{OBSERVATIONS AND RESULTS}

Table 1: Demographic characteristic of patients - Gender

\begin{tabular}{|l|l|}
\hline Gender & Total number of patients \\
\hline Male & 34 \\
\hline Female & 16 \\
\hline Total & $\mathbf{5 0}$ \\
\hline
\end{tabular}

\section{Gender Distribution}

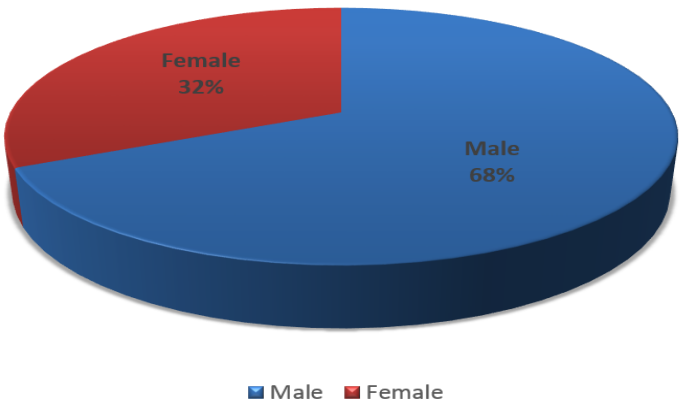

Figure 1: Gender Distribution

There were 34 males inthe study group with the rest 16 patients being female.

Table 2: Age

Age (Years)

\begin{tabular}{|l|l|}
\hline $\mathrm{n}$ & 50 \\
\hline Mean $\pm \mathrm{SD}$ & $11.3 \pm 1.92$ \\
\hline Median & 12 \\
\hline Min-Max & $8-16$ \\
\hline
\end{tabular}

Here there were 50 patientsobserved whose average age was 11.3 years with standard deviation 1.92. Minimum age was observed 8 years and maximum age was observed 16 years.

Table 3: Weight

\begin{tabular}{|l|l|l|}
\hline Weight (kgs) & \multicolumn{2}{l|}{} \\
\hline & At the start of study & After 3 months \\
\hline $\mathrm{n}$ & 50 & 50 \\
\hline Mean \pm SD & $32.05 \pm 6.17$ & $32.09 \pm 6.37$ \\
\hline Median & 30.56 & 30.79 \\
\hline Min-Max & $20.47-48.52$ & $20.58-50.63$ \\
\hline
\end{tabular}

Here there were 50 patients observed.

Average weight at the start of study was $32.05 \mathrm{kgs}$ with standard deviation 6.17. Minimum weight was observed 20.47 and maximum weight was observed 48.52 .

Average weight at after 3 months of study was $32.09 \mathrm{kgs}$ with standard deviation 6.37. Minimum weight was observed 20.58 and maximum weight was observed 50.63 .

Table 4: Height

\begin{tabular}{|l|l|l|}
\hline Height (cms) & \multicolumn{2}{|l|}{} \\
\hline & At the start of study & After 3 months \\
\hline $\mathrm{n}$ & 50 & 50 \\
\hline Mean \pm SD & $136.26 \pm 9.96$ & $136.57 \pm 9.90$ \\
\hline Median & 137.65 & 137.95 \\
\hline Min-Max & $118.7-162.5$ & $119.3-162.5$ \\
\hline
\end{tabular}

Here there were 50 patients observed.

Average height at the start of study was $136.26 \mathrm{cms}$ with standard deviation 9.96. Minimum height was observed 118.7 and maximum height was observed 162.5 
Average height at after 3 months of study was $136.57 \mathrm{cms}$ with standard deviation 9.90. Minimum height was observed 119.3 and maximum height was observed 162.5 .

Table 5: Descriptive summary of Laboratory parameters

\begin{tabular}{|c|c|c|}
\hline & At the start of study & After 3 months \\
\hline \multicolumn{3}{|l|}{ HB } \\
\hline $\mathrm{n}$ & 50 & 50 \\
\hline Mean \pm SD & $8.41 \pm 2.44$ & $9.59 \pm 1.9$ \\
\hline Median & 8.25 & 9.65 \\
\hline Min-Max & $3.2-13.2$ & 5.8-13.5 \\
\hline \multicolumn{3}{|l|}{ TLC } \\
\hline $\mathrm{n}$ & 50 & 50 \\
\hline Mean \pm SD & $11059 \pm 5029.6$ & $8908.6 \pm 3661$ \\
\hline Median & 10700 & 8500 \\
\hline Min-Max & $3600-29100$ & $1800-22100$ \\
\hline \multicolumn{3}{|l|}{ Calcium } \\
\hline $\mathrm{n}$ & 50 & 50 \\
\hline Mean \pm SD & $7.94 \pm 1.59$ & $8.4 \pm 1.45$ \\
\hline Median & 8.3 & 8.6 \\
\hline Min-Max & $3.7-11.8$ & $1.2-11.4$ \\
\hline \multicolumn{3}{|l|}{ Po4 } \\
\hline $\mathrm{n}$ & 50 & 50 \\
\hline Mean \pm SD & $5.9 \pm 2.63$ & $4.47 \pm 1.47$ \\
\hline Median & 5.7 & 4.35 \\
\hline Min-Max & $1.2-11.5$ & $1.2-7.8$ \\
\hline \multicolumn{3}{|l|}{ Albumin } \\
\hline $\mathrm{n}$ & 50 & 50 \\
\hline Mean \pm SD & $3.02 \pm 0.25$ & $3.03 \pm 0.23$ \\
\hline Median & 3.1 & 3.1 \\
\hline Min-Max & $2-3.4$ & $2.5-3.4$ \\
\hline \multicolumn{3}{|l|}{$\mathrm{iPTH}$} \\
\hline $\mathrm{n}$ & 50 & 50 \\
\hline Mean \pm SD & $505.8 \pm 244$ & $418.6 \pm 224.8$ \\
\hline Median & 442 & 375 \\
\hline Min-Max & $116-1230$ & $57.39-1210$ \\
\hline \multicolumn{3}{|l|}{ Urea } \\
\hline $\mathrm{n}$ & 50 & 50 \\
\hline Mean \pm SD & $152.54 \pm 107.5$ & $84.88 \pm 41.14$ \\
\hline Median & 110.5 & 74.5 \\
\hline Min-Max & $26-584$ & $26-204$ \\
\hline \multicolumn{3}{|l|}{ Creatinine } \\
\hline $\mathrm{n}$ & 50 & 50 \\
\hline Mean \pm SD & $5.86 \pm 3.6$ & $4.58 \pm 2.26$ \\
\hline Median & 4.8 & 4.5 \\
\hline Min-Max & $0.4-15.3$ & $0.4-11.3$ \\
\hline \multicolumn{3}{|l|}{ Sr.IRON } \\
\hline $\mathrm{n}$ & 50 & 50 \\
\hline Mean \pm SD & $52.96 \pm 28.30$ & $65.74 \pm 44.21$ \\
\hline Median & 47 & 51 \\
\hline Min-Max & $9-127$ & $19-226$ \\
\hline
\end{tabular}

Here there were 50 patients observed.

Average HB at the start of study was 8.41 with standard deviation 2.44 and at after 3 months of study was 9.59 with standard deviation 1.9.

Average TLC at the start of study was 11059 with standard deviation 5029.6 and at after 3 months of study was 8908.6 with standard deviation 3661 .

Average Calcium at the start of study was 7.94 with standard deviation 1.59 and at after 3 months of study was 8.4 with standard deviation 1.45 .

Average Po4 at the start of study was 5.9 with standard deviation 2.63 and at after 3 months of study was 4.47 with standard deviation 1.47.

Average Albumin at the start of study was 3.02 with standard deviation 0.25 and at after 3 months of study was 3.03 with standard deviation 0.23 .

Average iPTH at the start of study was 505.8 with standard deviation 244 and at after 3 months of study was 418.6 with standard deviation 224.8.

Average Urea at the start of study was 152.54 with standard deviation 107.5 and at after 3 months of study was 84.88 with standard deviation 41.14 .

Average Creatinine at the start of study was 5.86 with standard deviation 3.6 and at after 3 months of study was 4.58 with standard deviation 2.26 .

Average Sr. Iron at the start of study was 52.96 with standard deviation 28.30 and at after 3 months of study was 65.74 with standard deviation 44.21 .

For detailed information, please refer the above table.

Table 6: Clinical spectrum of patients with CKD on hemodialysis

\begin{tabular}{|l|l|l|}
\hline & Number of patients & percentages of patients \\
\hline GLOMERULAR & 27 & $54 \%$ \\
\hline CAKUT & 12 & $24 \%$ \\
\hline UNKNOWN & 10 & $20 \%$ \\
\hline TUBULAR & 1 & $2 \%$ \\
\hline Total & 50 & $100 \%$ \\
\hline
\end{tabular}

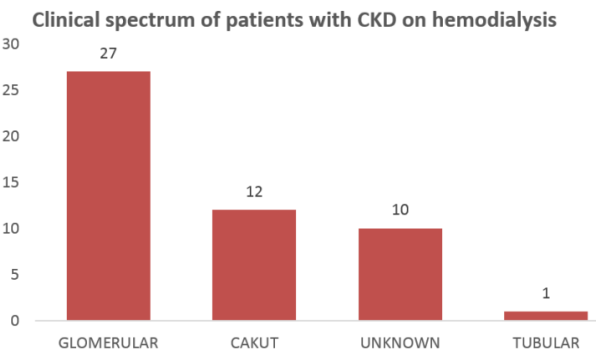

Figure 2: Clinical spectrum of patients with CKD on hemodialysis

Here there were 50 patients observed. The main causes of CKDwere glomerular diseases (54\%) followed by CAKUT (24\%), unknown (20\%) and TUBULAR (2\%).

Table 7: Different types of Glomerular disease

\begin{tabular}{|l|l|l|}
\hline & Number of patients & $\begin{array}{l}\text { percentages of } \\
\text { patients }\end{array}$ \\
\hline FSGS & 17 & $63.0 \%$ \\
\hline MPGN & 6 & $22.2 \%$ \\
\hline SLE NEPHRITIS & 2 & $7.4 \%$ \\
\hline HUS & 1 & $3.7 \%$ \\
\hline MCD & 1 & $3.7 \%$ \\
\hline Total & 27 & $100 \%$ \\
\hline
\end{tabular}

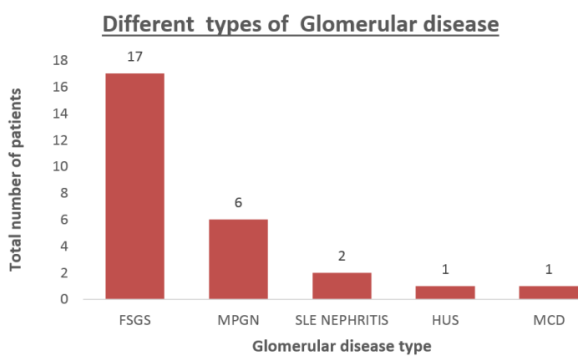

Figure 3: Different types of Glomerular disease

Here there were 27 patients had glomerular diseases, most of the patients with FSGS(63\%) followed by MPGN (22.2\%) and SLE NEPHRITIS (7.4\%).

Table 8: Different types of CAKUT disease

\begin{tabular}{|c|c|c|}
\hline & $\begin{array}{c}\text { Number of } \\
\text { patients }\end{array}$ & $\begin{array}{c}\text { percentages of } \\
\text { patients }\end{array}$ \\
\hline PUV & 7 & $58.33 \%$ \\
\hline RENAL DYSPLASIA & 3 & $25.00 \%$ \\
\hline PCKD & 1 & $8.33 \%$ \\
\hline SINGLE KIDNEY HDUN & 1 & $8.33 \%$ \\
\hline Total & 12 & $100 \%$ \\
\hline
\end{tabular}




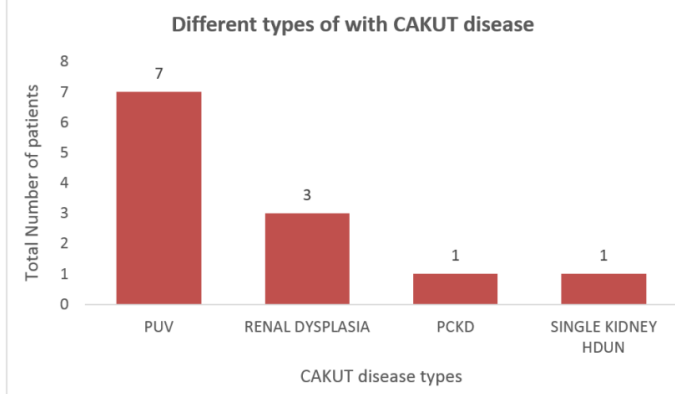

Figure 4: Different types of with CAKUT disease

Here there were 13 patients had CAKUT diseases, most of the patients with PUV (58.33\%) followed by Renal Dysplasia (25 $\%)$

Mean Difference in Growth parameters of pediatric hemodialysis patients

Table 9: Mean Difference in weightinpediatrichemodialysis patients

\begin{tabular}{|l|l|l|l|}
\hline & & & \\
\hline $\begin{array}{l}\text { At the start of } \\
\text { study }\end{array}$ & Observed value & $\mathrm{n}$ & 50 \\
\hline & & Mean \pm SD & $32.05 \pm 6.17$ \\
\hline & & Median & 30.56 \\
\hline & & Min-Max & $20.47-48.52$ \\
\hline & & & \\
\hline $\begin{array}{l}\text { After 3 months } \\
\text { of study }\end{array}$ & Observed value & $\mathrm{n}$ & 50 \\
\hline & & Mean \pm SD & $32.09 \pm 6.37$ \\
\hline & & Median & 30.79 \\
\hline & & Min-Max & $20.58-50.63$ \\
\hline & & & \\
\hline & $\begin{array}{l}\text { Change from } \\
\text { the start of the } \\
\text { study }\end{array}$ & n & 50 \\
\hline & & Mean \pm SD & $0.033 \pm 1.3$ \\
\hline & & p- Value* & $\mathbf{0 . 8 5}$ \\
\hline & & & \\
\hline
\end{tabular}

* p value calculated by using paired t test.

\section{DISCUSSION-}

There is no significant weight change after 3 months in pediatrichemodialysis ( $\mathrm{p}$ value $=0.85$ )

Table 10: Mean Difference in heightinpediatric hemodialysis patients

\begin{tabular}{|l|l|l|l|}
\hline $\begin{array}{l}\text { At the start of } \\
\text { study }\end{array}$ & $\begin{array}{l}\text { Observed } \\
\text { value }\end{array}$ & $\mathrm{n}$ & 50 \\
\hline & & Mean \pm SD & $136.26 \pm 9.96$ \\
\hline & & Median & 137.65 \\
\hline & & Min-Max & $118.7-162.5$ \\
\hline $\begin{array}{l}\text { After 3 months of } \\
\text { tudy }\end{array}$ & $\begin{array}{l}\text { Observed } \\
\text { value }\end{array}$ & $\mathrm{n}$ & 50 \\
\hline & & Mean \pm SD & $136.57 \pm 9.90$ \\
\hline & & Median & 137.95 \\
\hline & & Min-Max & $119.3-162.5$ \\
\hline & $\begin{array}{l}\text { Change from } \\
\text { the start of } \\
\text { the study }\end{array}$ & $\mathrm{n}$ & 50 \\
\hline & & Mean \pm SD & $0.308 \pm 0.32$ \\
\hline & & $\mathrm{p}-$ Value & $<0.00001$ \\
\hline
\end{tabular}

$-^{*}$ p value calculated by using paired t test.

\section{DISCUSSION-}

There is significant height change after 3 months in pediatrichemodialysis ( $\mathrm{p}$ value $=<0.00001$ ).

Mean Difference in Laboratory parameters by outcome in pediatrichemodialysis

Table 11: Mean Difference in HB by outcome in pediatric hemodialysis

\begin{tabular}{|c|c|c|c|}
\hline END OF STUDY & & & \\
\hline At the start of & Observed value & $\mathrm{n}$ & 30 \\
\hline & & Mean $\pm \mathrm{SD}$ & $8.65 \pm 2.41$ \\
\hline & & Median & 8.25 \\
\hline & & Min-Max & 3.4-12.2 \\
\hline After 3 months of & Observed value & $\mathrm{n}$ & 30 \\
\hline & & Mean \pm SD & $9.43 \pm 2.11$ \\
\hline & & Median & 9.45 \\
\hline & & Min-Max & $5.8-13.5$ \\
\hline & $\begin{array}{l}\text { Change from } \\
\text { the start of the } \\
\text { study }\end{array}$ & $\mathrm{n}$ & 30 \\
\hline & & Mean $\pm \mathrm{SD}$ & $0.78 \pm 2.85$ \\
\hline & & p-Value* & 0.145 \\
\hline $\begin{array}{l}\text { TERMINATION } \\
\text { OF DIALYSIS }\end{array}$ & & & \\
\hline At the start of & Observed value & $\mathrm{n}$ & 9 \\
\hline & & Mean \pm SD & $8.18 \pm 2.61$ \\
\hline & & Median & 8.1 \\
\hline & & Min-Max & $4.7-13.2$ \\
\hline After 3 months of & Observed value & $\mathrm{n}$ & 9 \\
\hline & & Mean $\pm \mathrm{SD}$ & $9.62 \pm 1.83$ \\
\hline & & Median & 9.9 \\
\hline & & Min-Max & 7.1-12.2 \\
\hline & $\begin{array}{l}\text { Change from } \\
\text { the start of the } \\
\text { study }\end{array}$ & $\mathrm{n}$ & 9 \\
\hline & & Mean $\pm \mathrm{SD}$ & $1.43 \pm 2.69$ \\
\hline & & p-Value* & 0.148 \\
\hline DIED & & & \\
\hline At the start of & Observed value & $\mathrm{n}$ & 6 \\
\hline & & Mean $\pm \mathrm{SD}$ & $8.57 \pm 3.24$ \\
\hline & & Median & 9.55 \\
\hline & & Min-Max & $3.2-11.43$ \\
\hline After 3 months of & Observed value & n & 6 \\
\hline & & Mean \pm SD & $9.98 \pm 1.67$ \\
\hline & & Median & 10.3 \\
\hline & & Min-Max & 7.7-11.9 \\
\hline & $\begin{array}{l}\text { Change from } \\
\text { the start of the } \\
\text { study }\end{array}$ & $\mathrm{n}$ & 6 \\
\hline & & Mean $\pm \mathrm{SD}$ & $1.41 \pm 3.83$ \\
\hline & & $p$ - Value* & 0.4 \\
\hline TRANSPLANT & & & \\
\hline At the start of & Observed value & n & 5 \\
\hline & & Mean \pm SD & $7.22 \pm 1.37$ \\
\hline & & Median & 6.5 \\
\hline & & Min-Max & $6-9$ \\
\hline After 3 months of & Observed value & $\mathrm{n}$ & 5 \\
\hline & & Mean \pm SD & $9.98 \pm 1.23$ \\
\hline & & Median & 9.4 \\
\hline & & Min-Max & $8.8-11.5$ \\
\hline
\end{tabular}




\begin{tabular}{|l|l|l|l|}
\hline & $\begin{array}{l}\text { Change from } \\
\text { the start of the } \\
\text { study }\end{array}$ & $\mathrm{n}$ & 5 \\
\hline & & Mean \pm SD & $2.76 \pm 1.97$ \\
\hline & & $\mathrm{p}-$ Value $^{*}$ & 0.035 \\
\hline
\end{tabular}

* p value calculated by using paired t test.

\section{DISCUSSION-}

There is no significant HB change after 3 months in End of Study $(\mathrm{p}$ value $=0.145)$, Termination of Dialysis $(\mathrm{p}$ value $=0.148$ ), in Died ( $p$ value $=0.4$ )andThere is significant HB change after 3 months Transplant( $\mathrm{p}$ value $=0.035$ ).

Table 12: Mean Difference in Calcium by outcome in pediatrichemodialysis

\begin{tabular}{|c|c|c|c|}
\hline END OF STUDY & & & \\
\hline At the start of & Observed value & $\mathrm{n}$ & 30 \\
\hline & & Mean $\pm \mathrm{SD}$ & $7.90 \pm 1.55$ \\
\hline & & Median & 8.6 \\
\hline & & Min-Max & $3.7-10.1$ \\
\hline After 3 months & Observed value & $\mathrm{n}$ & 30 \\
\hline & & Mean $\pm \mathrm{SD}$ & $8.61 \pm 1.06$ \\
\hline & & Median & 8.55 \\
\hline & & Min-Max & $6.1-11.4$ \\
\hline & $\begin{array}{l}\text { Change from } \\
\text { the start of the } \\
\text { study }\end{array}$ & $\mathrm{n}$ & 30 \\
\hline & & Mean $\pm \mathrm{SD}$ & $0.71 \pm 1.38$ \\
\hline & & $p$ - Value* & 0.008 \\
\hline $\begin{array}{l}\text { TERMINATION } \\
\text { OF DIALYSIS }\end{array}$ & & & \\
\hline At the start of & Observed value & $\mathrm{n}$ & 9 \\
\hline & & Mean $\pm \mathrm{SD}$ & $7.95 \pm 0.92$ \\
\hline & & \begin{tabular}{|l|} 
Median \\
\end{tabular} & 8.5 \\
\hline & & Min-Max & $6.4-9.5$ \\
\hline After 3 months & Observed value & $\mathrm{n}$ & 9 \\
\hline & & Mean $\pm \mathrm{SD}$ & $8.38 \pm 1.06$ \\
\hline & & Median & 8.55 \\
\hline & & Min-Max & $6.1-11.4$ \\
\hline & $\begin{array}{l}\text { Change from } \\
\text { the start of the } \\
\text { study }\end{array}$ & $\mathrm{n}$ & 9 \\
\hline & & Mean $\pm \mathrm{SD}$ & $0.43 \pm 1.84$ \\
\hline & & p-Value* & 0.50 \\
\hline DIED & & & \\
\hline At the start of & Observed value & $\mathrm{n}$ & 6 \\
\hline & & Mean \pm SD & $8.85 \pm 2.09$ \\
\hline & & \begin{tabular}{|l|} 
Median \\
\end{tabular} & 8.9 \\
\hline & & Min-Max & $5.2-11.4$ \\
\hline After 3 months & Observed value & $\mathrm{n}$ & 6 \\
\hline & & Mean $\pm \mathrm{SD}$ & $7.06 \pm 3.06$ \\
\hline & & \begin{tabular}{|l|} 
Median \\
\end{tabular} & 8.35 \\
\hline & & Min-Max & $1.2-9.4$ \\
\hline & $\begin{array}{l}\text { Change from } \\
\text { the start of the } \\
\text { study }\end{array}$ & $\mathrm{n}$ & 6 \\
\hline & & Mean $\pm \mathrm{SD}$ & $-1.78 \pm 4.46$ \\
\hline & & p-Value* & 0.37 \\
\hline TRANSPLANT & & & \\
\hline $\begin{array}{l}\text { At the start of } \\
\text { study }\end{array}$ & Observed value & $\mathrm{n}$ & 5 \\
\hline
\end{tabular}

\begin{tabular}{|c|c|c|c|}
\hline & & Mean \pm SD & $7.16 \pm 0.68$ \\
\hline & & Median & 6.9 \\
\hline & & Min-Max & $6.5-8.3$ \\
\hline \multirow{7}{*}{$\begin{array}{l}\text { After } 3 \text { months } \\
\text { of study }\end{array}$} & Observed value & $\mathrm{n}$ & 5 \\
\hline & & Mean \pm SD & $9.1 \pm 0.81$ \\
\hline & & Median & 9.1 \\
\hline & & Min-Max & $7.9-10.1$ \\
\hline & $\begin{array}{l}\text { Change from the } \\
\text { start of the study }\end{array}$ & $\mathrm{n}$ & 5 \\
\hline & & Mean \pm SD & $1.78 \pm 0.85$ \\
\hline & & p-Value* & 0.0072 \\
\hline
\end{tabular}

* p value calculated by using paired t test.

\section{DISCUSSION-}

There is significant change in calcium after 3 months in End of Study $(p$ value $=0.008$ ), Transplant $(p v a l u e ~=0.0072)$ and There is no significant change in calcium after 3 months inTermination of Dialysis $(p$ value $=0.50)$, Died $(p$ value $=0.37$ )

Table 13: Mean Difference in Po4 by outcome in pediatric hemodialysis

\begin{tabular}{|c|c|c|c|}
\hline \multicolumn{4}{|l|}{ END OF STUDY } \\
\hline \multirow[t]{4}{*}{$\begin{array}{l}\text { At the start of } \\
\text { study }\end{array}$} & Observed value & $\mathrm{n}$ & 30 \\
\hline & & Mean \pm SD & $5.89 \pm 2.77$ \\
\hline & & Median & 5.4 \\
\hline & & Min-Max & $1.9-11.5$ \\
\hline \multirow{7}{*}{$\begin{array}{l}\text { After } 3 \text { months } \\
\text { of study }\end{array}$} & Observed value & $\mathrm{n}$ & 30 \\
\hline & & Mean \pm SD & $4.39 \pm 1.42$ \\
\hline & & \begin{tabular}{|l|} 
Median \\
\end{tabular} & 4.35 \\
\hline & & Min-Max & $1.2-7.8$ \\
\hline & $\begin{array}{l}\text { Change from } \\
\text { the start of the } \\
\text { study }\end{array}$ & $\mathrm{n}$ & 30 \\
\hline & & Mean $\pm \mathrm{SD}$ & $-1.5 \pm 3.41$ \\
\hline & & p-Value* & 0.023 \\
\hline \multicolumn{4}{|l|}{$\begin{array}{l}\text { TERMINATION } \\
\text { OF DIALYSIS }\end{array}$} \\
\hline \multirow{4}{*}{$\begin{array}{l}\text { At the start of } \\
\text { study }\end{array}$} & Observed value & $\mathrm{n}$ & 9 \\
\hline & & Mean $\pm \mathrm{SD}$ & $5.4 \pm 2.4$ \\
\hline & & \begin{tabular}{|l|} 
Median \\
\end{tabular} & 4.9 \\
\hline & & Min-Max & $2.9-9.1$ \\
\hline \multirow{7}{*}{$\begin{array}{l}\text { After } 3 \text { months } \\
\text { of study }\end{array}$} & Observed value & $\mathrm{n}$ & 9 \\
\hline & & Mean $\pm \mathrm{SD}$ & $4.5 \pm 1.45$ \\
\hline & & Median & 4.6 \\
\hline & & Min-Max & $2.6-6.5$ \\
\hline & $\begin{array}{l}\text { Change from } \\
\text { the start of the } \\
\text { study }\end{array}$ & $\mathrm{n}$ & 9 \\
\hline & & Mean $\pm \mathrm{SD}$ & $-0.88 \pm 2.35$ \\
\hline & & p-Value * & 0.28 \\
\hline \multicolumn{4}{|l|}{ DIED } \\
\hline \multirow{4}{*}{$\begin{array}{l}\text { At the start of } \\
\text { study }\end{array}$} & Observed value & $\mathrm{n}$ & 6 \\
\hline & & Mean $\pm \mathrm{SD}$ & $5.55 \pm 3.12$ \\
\hline & & \begin{tabular}{|l|} 
Median \\
\end{tabular} & 5.95 \\
\hline & & Min-Max & $1.2-10.4$ \\
\hline \multirow{4}{*}{$\begin{array}{l}\text { After } 3 \text { months } \\
\text { of study }\end{array}$} & Observed value & $\mathrm{n}$ & 6 \\
\hline & & Mean $\pm \mathrm{SD}$ & $4.36 \pm 2.19$ \\
\hline & & Median & 3.4 \\
\hline & & Min-Max & $2.5-7.3$ \\
\hline
\end{tabular}




\begin{tabular}{|l|l|l|l|}
\hline & $\begin{array}{l}\text { Change from } \\
\text { the start of the } \\
\text { study }\end{array}$ & $\mathrm{n}$ & 6 \\
\hline & & Mean $\pm \mathrm{SD}$ & $-1.18 \pm 2.47$ \\
\hline & & $\mathrm{p}$ - Value* & 0.29 \\
\hline TRANSPLANT & & & \\
\hline $\begin{array}{l}\text { At the start of } \\
\text { study }\end{array}$ & Observed value & $\mathrm{n}$ & 5 \\
\hline & & Mean $\pm \mathrm{SD}$ & $7.34 \pm 1.48$ \\
\hline & & Median & 7.8 \\
\hline & & Min-Max & $5.4-8.9$ \\
\hline $\begin{array}{l}\text { After 3 months } \\
\text { of study }\end{array}$ & Observed value & $\mathrm{n}$ & 5 \\
\hline & & Mean $\pm \mathrm{SD}$ & $4.98 \pm 1.13$ \\
\hline & & Median & 5.5 \\
\hline & & Min-Max & $3.7-6$ \\
\hline & $\begin{array}{l}\text { Change from } \\
\text { the start of the } \\
\text { study }\end{array}$ & $\mathrm{n}$ & 5 \\
\hline & & Mean $\pm \mathrm{SD}$ & $-2.36 \pm 1.83$ \\
\hline & & $\mathrm{p}-$ Value* & 0.045 \\
\hline
\end{tabular}

* p value calculated by using paired t test.

\section{DISCUSSION-}

There is significant change in Po4 after 3 months in End of Study ( $p$ value $=0.023$ ), Transplant(pvalue $=0.045$ ) and There is no significant change in Po4 after 3 months in Termination of Dialysis $(p$ value $=0.28$ ), Died ( $p$ value $=0.29$ )

Table 14: Mean Difference in iPTH by outcome in pediatric hemodialysis

\begin{tabular}{|c|c|c|c|}
\hline END OF STUD & & & \\
\hline $\begin{array}{l}\text { At the start of } \\
\text { study }\end{array}$ & $\begin{array}{l}\text { Observed } \\
\text { value }\end{array}$ & $\mathrm{n}$ & 30 \\
\hline & & Mean \pm SD & $500.36 \pm 213.8$ \\
\hline & & Median & 446.5 \\
\hline & & Min-Max & $208-952$ \\
\hline $\begin{array}{l}\text { After } 3 \text { months } \\
\text { of study }\end{array}$ & $\begin{array}{l}\text { Observed } \\
\text { value }\end{array}$ & $\mathrm{n}$ & 30 \\
\hline & & Mean $\pm \mathrm{SD}$ & $409.5 \pm 230.5$ \\
\hline & & Median & 230.58 \\
\hline & & Min-Max & $57.39-1210$ \\
\hline & $\begin{array}{l}\text { Change from } \\
\text { the start of } \\
\text { the study }\end{array}$ & n & 30 \\
\hline & & Mean \pm SD & $-90.84 \pm 327$ \\
\hline & & $p$ - Value* & 0.13 \\
\hline $\begin{array}{l}\text { TERMINATION } \\
\text { OF DIALYSIS }\end{array}$ & & & \\
\hline $\begin{array}{l}\text { At the start of } \\
\text { study }\end{array}$ & $\begin{array}{l}\text { Observed } \\
\text { value }\end{array}$ & $\mathrm{n}$ & 9 \\
\hline & & Mean \pm SD & $500.36 \pm 213.8$ \\
\hline & & Median & 446.5 \\
\hline & & Min-Max & $208-952$ \\
\hline $\begin{array}{l}\text { After } 3 \text { months } \\
\text { of study }\end{array}$ & $\begin{array}{l}\text { Observed } \\
\text { value }\end{array}$ & $\mathrm{n}$ & 9 \\
\hline & & Mean \pm SD & $486.88 \pm 269.5$ \\
\hline & & Median & 447 \\
\hline & & Min-Max & $189-967$ \\
\hline & $\begin{array}{l}\text { Change from } \\
\text { the start of } \\
\text { the study }\end{array}$ & n & 9 \\
\hline & & Mean \pm SD & \begin{tabular}{|l}
$-30.57 \pm$ \\
258.12 \\
\end{tabular} \\
\hline & & p-Value* & 0.73 \\
\hline
\end{tabular}

\begin{tabular}{|c|c|c|c|}
\hline DIED & & & \\
\hline \multirow[t]{4}{*}{$\begin{array}{l}\text { At the start of } \\
\text { study }\end{array}$} & $\begin{array}{l}\text { Observed } \\
\text { value }\end{array}$ & $\mathrm{n}$ & 6 \\
\hline & & $\begin{array}{l}\text { Mean } \pm \\
\text { SD }\end{array}$ & $449.66 \pm 270.8$ \\
\hline & & Median & 419 \\
\hline & & Min-Max & $116-943$ \\
\hline \multirow[t]{7}{*}{$\begin{array}{l}\text { After } 3 \text { months } \\
\text { of study }\end{array}$} & $\begin{array}{l}\text { Observed } \\
\text { value }\end{array}$ & $\mathrm{n}$ & 6 \\
\hline & & $\begin{array}{l}\text { Mean } \pm \\
\text { SD }\end{array}$ & $449.66 \pm 270.8$ \\
\hline & & Median & 419 \\
\hline & & Min-Max & $116-943$ \\
\hline & $\begin{array}{l}\text { Change from } \\
\text { the start of } \\
\text { the study }\end{array}$ & n & 6 \\
\hline & & $\begin{array}{l}\text { Mean } \pm \\
\text { SD }\end{array}$ & $0.0 \pm 0.0$ \\
\hline & & p-Value ${ }^{*}$ & - \\
\hline \multicolumn{4}{|l|}{ TRANSPLANT } \\
\hline \multirow[t]{4}{*}{$\begin{array}{l}\text { At the start of } \\
\text { study }\end{array}$} & $\begin{array}{l}\text { Observed } \\
\text { value }\end{array}$ & $\mathrm{n}$ & 5 \\
\hline & & $\begin{array}{l}\text { Mean } \pm \\
\text { SD }\end{array}$ & $640.2 \pm 364.01$ \\
\hline & & Median & 587 \\
\hline & & Min-Max & $339-1230$ \\
\hline \multirow[t]{7}{*}{$\begin{array}{l}\text { After } 3 \text { months } \\
\text { of study }\end{array}$} & $\begin{array}{l}\text { Observed } \\
\text { value }\end{array}$ & $\mathrm{n}$ & 5 \\
\hline & & $\begin{array}{l}\text { Mean } \pm \\
\text { SD } \\
\end{array}$ & $382.84 \pm 114.26$ \\
\hline & & Median & 367 \\
\hline & & Min-Max & $288.2-572$ \\
\hline & $\begin{array}{l}\text { Change from } \\
\text { the start of } \\
\text { the study }\end{array}$ & n & 5 \\
\hline & & $\begin{array}{l}\text { Mean } \pm \\
\text { SD }\end{array}$ & $-257.36 \pm 389.72$ \\
\hline & & $p$ - Value* & 0.21 \\
\hline
\end{tabular}

* p value calculated by using paired t test.

\section{DISCUSSION-}

There is no significant change in iPTH after 3 months in End of Study $(p$ value $=0.13$ ), Transplant (pvalue $=0.21$ ) and Termination of Dialysis ( $p$ value $=0.73$ )

Table 15: Outcome of the study

\begin{tabular}{|c|c|c|}
\hline & $\begin{array}{c}\text { Number of } \\
\text { patients }\end{array}$ & $\begin{array}{c}\text { percentages of } \\
\text { patients }\end{array}$ \\
\hline End of Study & 30 & $60 \%$ \\
\hline Termination Of Dialysis & 9 & $18 \%$ \\
\hline Died & 6 & $12 \%$ \\
\hline Transplant & 5 & $10 \%$ \\
\hline Total & 50 & $100 \%$ \\
\hline
\end{tabular}

\section{Outcome}

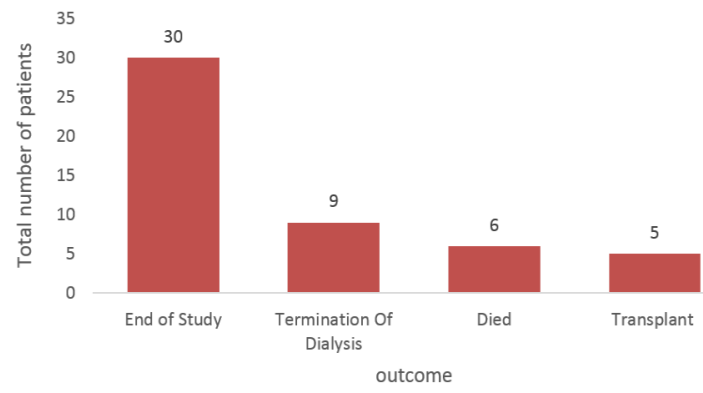

Figure 5: Outcome of the study 
Overall 50 patients enrolled in the study in which 30 patients (60\%) completed the study, 9patients (18\%) were termination of dialysis, 6 patients $(12 \%)$ died and 5 patients $(10 \%)$ goes for the Transplant.

\section{DISCUSSION}

Chronic Kidney Disease (CKD) is an insidious and irreversible condition that eventually progresses to end stage renal failure. It is an important cause of morbidity and mortality in children. The magnitude of CKD varies from one geographical area to another due to genetic and environmental factors worldwide.

An understanding of the important causes of CKD in any country is important as it may guide the distribution of limited resources towards its prevention. Thereafter monitoring and management depends on the stage of CKD according to the cause. Thus a sound knowledge of the children likely to develop Stage 5 CKD helps utilise the resources in monitoring these children and directing all intervention programs toward retarding the progression of disease. In children presenting at an older age chronic glomerulonephritis is more common $A$ similar trend has been reported from other developing countries. As against this, the data from developed countries reveals that besides obstructive uropathy, congenital aplasia/hypoplasia/dysplasia is an important cause for CKD in children.

In our study as shown in fig $l$ out of total 50 patients there were $34(68 \%)$ male and 16(32\%) female. In most studies prevalence of CKD is found to be more in male children .

Hari $\mathrm{P}^{[46]}$ et al also found similar results. They had total 305 cases of CKD with $73.77 \%$ patients were male and $26.23 \%$ patients were female.

Gulati $\mathrm{S}^{[2]]}$ et al found a male to female ratio of 2.2 Mong Hiep $\mathrm{TT}^{[23]}$ et al found $54 \%$ male patients and $46 \%$ female patients.

Madani $\mathrm{K}$ et $\mathrm{al}^{[20]}$ investigated chronic renal failure (CRF) in 166 Iranian childrenfrom July 1991 to June 1999.they also found male prevalence of CKD, in children out of total 166 cases there were $95(57.22 \%)$ boys and $71(42.77 \%)$ girls.

In our study as shown in table -6 and fig- 2 glomerulopathys commonest cause of CKD in children. In our study out of 50 cases $27(54 \%)$ cases wer found to be having glomeruolnephritis as a cause of CKD. Out of 27 patients of glomerulonephritis there are 17 cases of FSGS(63\%)6 cases of MPGN(22.2\%), 2 cases of SLE nephritis(7.4\%), l case of $\operatorname{HUS}(3.7 \%)$, and 1 case of $\operatorname{MCD}(3.7 \%)$.

Gulati S et al ${ }^{[21]}$ found glomerulonephritis as a cause of CKDin $37.5 \%$ cases which was most common cause of CKDin their study.

HariP $^{[46]}$ et al reported Chr. glomerulonephritis as a cause of CKD in only $27.5 \%$ of cases. The median age of cases in study were 8 years where as in our study it was 12 years. And out of 305 cases 96 cases(31.47\%) were under 5 years of age. This could be a reason of varying result seen in our study.

Hari $\mathrm{P}$ et al also reported Chr. glomerulonephritis as commonest cause of CKD after first decade and median age in our study was 12 years, this could be another reason that we got such high percentage of cases with glomerulonephritis.

Whereas studies done in other developing countries shows result similar to us as glomerulonephritis being the commonest cause of CKD.

Mong Hiep TT et $\mathrm{al}^{[23]}$ reported glomerulonephritis as commonest cause of CKD seen in $30.3 \%$ cases in their study in Vietnamese children.

In our study congenital anomaly of kidney and urinary tract is second major cause of CKD in children. Majority of cases of CAKUT(24\%) are due to PUV(58.33\%). Second most common cause among CAKUT we found is small kidney at early age most likely renal dyplasia(25\%). Other causes PCKD(8.3\%) and single kidney HDUN(8.3\%).

In study done by Gulati $\mathrm{S}$ et $\mathrm{al}^{[21]} 41 \%$ cases were due to congenital anomaly of kidney and urinary tract with PUV being the most common among CAKUT causes.

In study done by Mong Hiep TT et al ${ }^{[23]}$ congenital structural anamoly was reported as second major cause of CKD in children (15.8\%).

$\mathrm{Al}-$ EisaA et $\mathrm{al}^{[17]}$ reported a very high prevalence of CAKUT as cause of CKD in Kuwaities children. $61.9 \%$ of patients were reported of having a congenital urologic malformation and majority of these cases of CKD are preventable. In their study $55.5 \%$ cases were under 5 years of age that may explain such high percentage of CKD due to congenital anomalywhereas in our study median age is 12. Another explanation they provided that genetic factor associated with consanguinity are an important factor leading to a high incidence of recessively transmitted hereditary diseases and congenital malformations .

In our study as shown in table 9 and figure 4 out of 50 cases :30 $(60 \%)$ cases were followed till the end of study $9(18 \%)$ cases terminated dialysis on parent's wish and dialysis may be continued at another centre.6 (12\%)cases died during the study period And 5 (10\%)cases underwent renal transplantation.

$2^{\text {nd }}$ Annual report of CKD registry of Indian society of nephrology ${ }^{[45]}$ presented in December 2007 by Dr. M. M. Rajapurkar ${ }^{27}$ as convener reported that out of a total number of 25340 population of India suffering from CKD and \& only $2.5 \%$ of patients are getting renal transplantation done.

Gulati $S$ et $\mathrm{al}^{[21]}$ reported A total of 10 out of 48 cases (21\%)received a renal allograft transplant.

Hari P et al ${ }^{[46]}$ reported that Of 91 (29.8\%) patients in end stage renal failure, 63 received hemodialysis for variable duration. Fifteen patients underwent live related renal transplantation; the remaining opted out of the dialysis and transplant program due to financial constraints.

In our study also 9 (18\%)patients opted out of dialysis.

Maintaining an appropriate care for children with ESRD in developing countries is quite difficult due to many factors including late referral of children with chronic kidney failure, poor acceptance of parents to ask medical service, limitation of financial resources to supply high-cost medication for replacement therapy, and poor logistic and availability of transplantation with the limitation of laws that restrict transplantation to living related donors and scarcity of trained personnel in pediatric nephrology and complexity of pediatric transplantation in such condition. Since our ESRD children have to be treated with hemodialysis for long periods, they are exposed to a high risk of complications. We found that the most common cause of ESRD was glomerular disease in our pediatric patients, followed by congenital anomaly of kidney and urinary tract.

\section{CONCLUSION}

- In children etiology of CKD is age dependent and vary according to geography and nationality. In this study we 
found glomerular disease and CAKUT as the major causes of CKD in children.

- In our study glomerular disease(54\%) are commonest cause of CKD with median age of cases 12 years. Second commonest causes were CAKUT (24\%) which is seen as more common cause of CKD in other studies with younger age groups.

- Maintaining an appropriate care for children with ESRD in developing countries is quite difficult due to many factors including late referral of children with chronic kidney failure, poor acceptance of parents to ask medical service, limitation of financial resources to supply high-cost medication for replacement therapy, and poor logistic and availability of transplantation with the limitation of laws that restrict transplantation to living related donors and complexity of pediatric transplantation in such condition.

- Majority of patients are referred late and only a few opt for renal replacement measures due to its high cost. Both these factors eventually lead to a poor outcome of CRF in our population.

- Due to poor logistic and availability of transplantation with the limitation of laws that restrict transplantation to living related donors and scarcity of trained personnel in pediatric nephrology and complexity of pediatric transplantation in such condition. Since our ESRD children have to be treated with hemodialysis for long periods, they are exposed to a high risk of complications.

- There is a greater need for establishing multiple pediatric haemodialysis centres all over India, including rural set up for increasing the long term survival in pediatric patients with CKD ,ESRD and improving their quality of life.

\section{CONFLICTS OF INTEREST :NONE}

ACKNOWLEDGEMENT:The authors want to thank the parents and the guardians who consented for the participation of their children in the study.

\section{REFERENCES}

1. Kolff WJ, Berk HTH, TerWelle M, van der Leg JW,vanDijk EC, van Noordwijk J. The artificial kidney: a dialyser with great area. Acta Med Scand. 1944;117:121-34

2. KolffWJ. First clinical experience with the artificial kidney. Ann Intern Med. 1965;62:608-19.

3. Merrill JP, Smith III S, Callahan III EJ, Thorn GW. The use of an artificial kidney. II. Clinical experience J Clin Invest. 1950;29:425-38.

4. Gruskin AB, Baluarte HJ, Dabbagh S. Hemodialysis and peritoneal dialysis. In: Edelman MC, editor. Pediatric kidney disease. Boston: Little Brown; 1992. p. 827.

5. US Renal Data System: USRDS 2004 Annual Data Report. Bethesda, MD, The National Institutes of Health, 2004.

6. McDonald SP, Craig JC: Long-term survival of children with end-stage renal disease. N Engl J Med 350:2654-2662, 2004

7. National Kidney Foundation: DOQI Clinical Practice Guidelines for Hemodialysis Adequacy. Am J Kidney Dis 30:S15-S66, 1997 (suppl2).

8. U.S. Renal Data System. USRDS 2009 annual data report: Atlas of chronic kidney disease and end-stage renal disease in the United States, National Institutes of Health, National Institute of Diabetes and Digestive and Kidney Diseases, Bethesda. 2009

9. Nissenson AR, Fine RN, editors. Handbook of dialysis therapy. 4th ed. Philadelphia: Saunders/Elsevier; 2008. 1583 p.

10. U.S. Renal Data System. USRDS 2008 annual data report: Atlas of chronic kidney disease and end-stage renal disease in the United States, National Institutes of Health, National Institute of Diabetes and Digestive and Kidney Diseases, Bethesda. 2008

11. Bourel M, Ardaillou R. Prevention andscreening of chronic renalfailure. Bull. Acad. Natl. Med. 2004; 188: 1455-68.

12. Goldstein SL. Overview of pediatric renal replacement therapy in acute renal failure. Artif Organs. 2003;27:781-5.

13. Warady BA, Schaefer F, Alexander S, editors. Pediatric dialysis. Second edition. New York: Springer; 2012. 825 p.

14. Levey AS, Coresh J, Balk E, Kausz AT, Levin A, Steffes MW, et al. National Kidney Foundationpractice guidelines for chronic kidney disease:evaluation, classification, and stratification. Ann Intern Med 2003; 139:137-47

15. M kanitker. Chronic kidney disease in children: an Indian prespective. Med j armed forces india .2009 Jan; 65(1): 45-49.

16. Harambat J, van Stralen KJ, Kim JJ, Tizard EJ. Epidemiology of chronic kidney disease in children. PediatrNephrol (Berlin, Germany). 2012;27(3):363-373.

17. Al-Eisa A, Naseef M, Al-Hamad N, Pinto R, Al-Shimeri N, Tahmaz M. Chronic renal failure in Kuwaiti children: an eight-year experience. PediatrNephrol. 2005;20:1781-1785. doi: 10.1007/s00467-005-2000-z.

18. Bek K, Akman S, Bilge I, Topaloğlu R, Calişkan S, Peru H, Cengiz N,
Söylemezoğlu O. Chronic kidney disease in children in Turkey. PediatrNephrol. 2009:24:797-806. doi: 10.1007/s00467-008-0998-4.

19. Hamed RM. The spectrum of chronic renal failure among Jordanian children. J Nephrol. 2002;15:130-135

20. Madani K, Otoukesh H, Rastegar A, Why S. Chronic renal failure in Iranian children. PediatrNephrol. 2001;16:140-144. doi: 10.1007/s004670000522.

21. Gulati S, Mittal S, Sharma RK, Gupta A. Etiology and outcome of chronic renal failure in Indian children. PediatrNephrol. 1999:13:594-596. doi: $10.1007 / \mathrm{s} 004670050750$.

22. Vachvanichsanong P, Dissaneewate P, McNeil E. Childhood chronic kidney disease in a developing country. PediatrNephrol. 2008;23:1143-1147. doi: 10.1007/s00467-008-0775-4

23. MongHiep TT, Janssen F, Ismaili K, Khai Minh D, VuongKiet D, Robert A. Etiology and outcome of chronic renal failure in hospitalized children in $\mathrm{Ho}$ Chi Minh City, Vietnam. PediatrNephrol. 2008;23:965-970. doi: 10.1007/s00467-008-0752-y.

24. Huong NT, Long TD, Bouissou F, Liem NT, Truong DM, Nga do K, Chien TT Bascands JL. Chronic kidney disease in children: the National Paediatric Hospital experience in Hanoi, Vietnam. Nephrology (Carlton) 2009, 14:722-727. doi: 10.1111/j.1440-1797.2009.01142.x.

25. Orta-Sibu N, Lopez M, Moriyon JC, Chavez JB. Renal diseases in children in Venezuela, South America. PediatrNephrol. 2002;17:566-569. doi: 10.1007/s00467-002-0892-4.

26. Miller ME, Williams JA. Chronic renal failure in Jamaican children-an update (2001-2006) West Indian Med J. 2009;58:231-234.

27. Anochie I, Eke F. Chronic renal failure in children: a report from Port Harcourt, Nigeria (1985-2000) PediatrNephrol. 2003;18:692-695.

28. Bhimma R, Adhikari M, Asharam K, Connolly C. The spectrum of chronic kidney disease (stages 2-5) in KwaZulu-Natal, South Africa. PediatrNephrol. 2008:23:1841-1846. doi: 10.1007/s00467-008-0871-5.

29. Ali el-TM, Abdelraheem MB, Mohamed RM, Hassan EG, Watson AR. Chronic renal failure in Sudanese children: aetiology and outcomes. PediatrNephrol. 2009;24:349-353. doi: 10.1007/s00467-008-1022-8.

30. Sethi S.K. Bunchman T Rainarupesh, Khervijay. Unique Considerations in Renal Replacement Therapy in Children: Core Curriculum 2014. Am J Kidney dis. 2014;63(2):329-345

31. Kaur, A. and Davenport, A. Hemodialysis for infants, children, and adolescents. Hemodiallnt, 2014;18:573-582. doi:10.1111/hdi.12163

32. Keshaviah P. Resource limitations and strategies for the treatment of uremia.. dialysis unit in the Himalayan foothills. Blood Purif. 2001;19(1):44-52.

33. Mani MK. Experience with a program for prevention of chronic renal failure in India. Kidney Int Suppl. 2005 Apr;(94):S75-78.

34. Agarwal SK, Dash SC, Irshad M, Raju S, Singh R, Pandey RM. Prevalence of chronic renal failure in adults in Delhi, India. Nephrol Dial Transplant. 2005 Aug;20(8):1638-42.

35. Modi GK, Jha V. The incidence of end-stage renal disease in India: a population-based study. Kidney Int. 2006 Dec;70(12):2131-3.

36. Fadrowski JJ, Frankenfield D, Amaral S, Brady T, Gorman GH, Warady B, et al. Children on long-term dialysis in the United States: findings from the 2005 ESRD clinical performance measures project. Am J Kidney Dis. 2007 Dec;50(6):958-66

37. Gorman G, Furth S, Hwang W, Parekh R, Astor B, Fivush B, et al. Clinical outcomes and dialysis adequacy in adolescent hemodialysis patients. Am Kidney Dis. 2006 Feb;47(2):285-93.

38. Chand DH, Brier M, Strife CF. Comparison of vascular access type in pediatrichemodialysis patients with respect to urea clearance, anemia management, and serum albumin concentration. American Journal of Kidney Diseases. 2005 Feb;45(2):303-8.

39. Chavers BM, Solid CA, Daniels FX, Chen S-C, Collins AJ, Frankenfield DL, et al. Hypertension in pediatric long-term hemodialysis patients in the United States. Clin JAm SocNephrol. 2009 Aug:4(8):1363-9.

40. Huong NTQ, Long TD, Bouissou F, Liem NT, Truong DM, Nga DK, et al. Chronic kidney disease in children: the National Paediatric Hospital experience in Hanoi, Vietnam. Nephrology (Carlton). 2009 Dec; 14(8):722-7.

41. Erkan E, Moritz M, Kaskel F. Impact of residual renal function in children on hemodialysis. PediatrNephrol. 2001 Nov; 16(11):858-61.

42. Youssef DM, Neemat-Allah MAA. Hemodialysis in children: eleven years in single center in Egypt. Iran J Kidney Dis. 2013 Nov;7(6):468-74.

43. UK Renal Registry 2010 14th Annual Report; Dr Ron Cullen;Southmead Hospital Bristol, UK.

44. U.S. Renal Data System USRDS 2013 Annual Data Report: Atlas of chronic kidney disease and end-stage renal disease in the United States, National Institute of Health, National Institute of Diabetes and Digestive and Kidney Diseases,Bethesda.2013.

45. CKD Registry Indian Society Of Nephrology 2007 Annual Report :Dr. M. M. Rajapurkar; Muljibhai Patel Society for Research in Nephro- Urology, Gujarat.

46. PankajHari,IshSingla K, Mantan M, Kanitkar M, Batra B, Bagga A. Chronic renal failure in children.Indian Pediatr40(11), 1035-1042. 